\title{
BUDAYA NARSISTIK \\ DALAM IKLAN PILKADA 2015
}

\author{
Prayanto Widyo Harsanto \\ Desain Komunikasi Visual, Fakultas Seni Rupa \\ Institut Seni Indonesia Yogyakarta \\ E-mail: prayantowh@ymail.com
}

\begin{abstract}
Abstrak
Ruang-ruang publik khususnya di perkotaan hampir di seluruh wilayah di Indonesia banyak diramaikan oleh pemasangan berbagai bentuk iklan. Baik itu iklan komersial yang menawarkan berbagai produk, maupun iklan-iklan yang berbau politik. Terlebih pada akhir tahun 2015 Indonesia menggelar pilkada serentak, tepatnya pada 9 Desember 2015. Lebih dari 200 daerah akan melakukan pemilihan kepala daerah (Pilkada), baik di tingkat kabupaten maupun tingkat propinsi. Tidak mengherankan bila di sepanjang jalan, di ruang-ruang publik mata dipaksa melihat iklan pilkada yang berbentuk baliho, spanduk, maupun poster. Dalam kajian ini digunakan visual methodologis dari Gillian Rose (2001) untuk mengkaji dengan mencermati objek material berupa iklan politik pilkada melalui sisi produksi, karya iklan itu sendiri, dan masyarakat yang mengkonsumsi. Fotografi menjadi salah satu elemen penting dalam iklan pilkada, dimana foto dilihat dari fungsinya adalah untuk membantu memperjelas dan memperteguh isi pesan iklan. Foto yang berupa sosok/seseorang calon kepala dan wakil kepala daerah selain merangsang perhatian pembaca, dan bisa juga hanya sebagai elemen visual saja. Dalam kasus iklan pilkada ini, penulis tertarik dengan hadirnya fotofoto tokoh yang terpampang pada baliho atau pada media luar ruang yang lain. Bertolak dari tampilnya tokoh tersebut ada hal yang menarik bila dicermati dari sisi fotografi khususnya dari sisi portraiture photography, yang bisa dilihat dari sisi ide, teknis, dan estetikanya. Selain itu juga bisa dlihat dari sisi psychophotography yaitu ditengarai adanya sifat narsis atau narsistik dari tampilnya sosok gambar/foto wajah kandidat yang memiliki rasa percaya diri yang sangat tinggi dan juga rasa ingin dikagumi oleh orang lain.
\end{abstract}

Kata Kunci: Portraiture Photography, Iklan, dan Pilkada

\section{NARCISSISM IN CAMPAIGN ADVERTISEMENT FOR REGIONAL HEAD ELECTIONS OF 2015}

\section{Abstract}

Public spaces in urban regions in almost all over Indonesia have been filled with many kinds of advertisements either commercial advertisements which offer various products or political advertisements. Due to he fact that there will be simultanous head region elections in more than 200 regions on December 9, 2015, many kinds of campaign advertisements exist in the form of billboards, banners, and posters.In this study, Gillian Rose's (2001) visual methodology was used to conduct a research by observing the material objects in the form of campaign advertisements for regional head elections from the perspective of production, the advertisments, and the people consuming them. Photography becomes an important 
element in these campaign advertisements for regional head elections as photographs can help illuminate and stengthen the points given in the advertisements. The photographs of the candidates can stimulate the audience's attention or only become the visual elements. In relation to these regional head elections, the researcher is interested in the figures portrayed in the billboards or in other outdoor media. Apart from the appearance of the figures, there are interesting things that can be observed especially about the portraiture photography in terms of idea, technique, and aesthetics. This can also be seen from the side of psychophotography in that there is a kind of narcisstic sides from the photographs of the candidates who have high confidence and narcissism.

Key words: portraiture photography, advertisements, head region elections

\section{A. Latar Belakang}

Saat ini kesadaran sebagian masyarakat untuk menggunakan iklan sudah tumbuh dan masyarakat mulai memahami betapa pentingnya beriklan untuk tujuan bermacam-macam sesuai kepentingannya masing-masing. Iklan menjadi sarana yang penting dan efektif untuk membentuk pencitraan atas produk ataupun jasa yang ditawarkan. Tidak hanya produk yang berupa barang saja, tetapi juga untuk kebutuhan yang bersifat personal branding. Pada dasarnya sebuah iklan mampu memberikan dorongan bagi audiensnya untuk membentuk atau menciptakan imajinasi/khayalan sesuai dengan tujuan yang ingin dicapai dalam komunikasi. Iklan merupakan hasil kebudayaan modern yang disadari atau tidak mempengaruhi tingkah laku masyarakat. Kadang untuk menambah daya pikatnya media iklan sering ditampilkan dengan citra-citra tertentu atau lebih tepatnya dengan perpaduan antara berbagai citra. Media iklan tidak hanya terbatas pada bahasa dan teks saja, melainkan mengembangkan lewat gambar atau simbol-simbol yang dapat dimengerti oleh audience.

Sosiolog konservatif Amerika Daniel Bell dalam buku Hikmat Budiman (2002: 63) mengatakan bahwa penemuan yang paling menakutkan dalam sejarah 
peradaban masyarakat kapitalis adalah iklan. Bell melihat bahwa dalam pelbagai kebiasaan hidup masyarakat yang selalu berubah saat ini, iklan telah memainkan peran yang sangat penting dalam merangsang keinginan masyarakat/massa. Sebuah masyarakat yang berubah dengan cepat oleh industri tentu saja didera kebingungan berkaitan dengan bentuk-bentuk tingkah laku, selera, pakaian dan lain sebagainya.

Komunikasi, dalam hal ini media massa, merupakan agen-agen perubahan sosial yang amat dinamis saat ini. Di lain pihak kita tidak bisa menyangkal bahwa pengaruh arus komunikasi massa dewasa ini bersifat sangat universal yang dampaknya dapat dirasakan sampai ke pelosok masyarakat terpencil di manapun di dunia ini. Hal ini sangat berdampak bagi proses pembentukan suata bangsa dan secara konkret dalam perubahan pola pikir dan tingkah laku masyarakat. Perkembangan pesat dalam teknologi informasi telah merevolusi cara kita berhubungan antara manusia satu dengan yang lainnya, serta membawa perubahan pada cara kita mengekspresikan diri. Perkembangan teknologi informasi juga menciptakaan alternatif baru bagi kelompok atau individu untuk bisa menampilkan identitas diri atau kelompoknya dalam pusat informasi (lewat internet/website, TV atau media yang lain).

Penulis merasa tergelitik ketika setiap hari melewati jalan-jalan yang dipenuhi poster, spanduk, baliho terutama menjelang hajatan besar seperti pemilu maupun pilkada. Kebanyakan iklan politik/pilkada cenderung mengumbar janji normatif yang sulit dilaksanakan jika mereka terpilih. Slogan dan janji yang mereka sampaikan sulit terealisasi karena tidak memiliki batasan dan tidak ada ukuran. Iklan kampanye pilkada dari tokoh politik maupun partai politik yang ditayangkan hanya mengumbar janji yang berpotensi merugikan rakyat. Media iklan tersebut berupa tulisan namun tidak lepas dari unsur gambar. Dalam hal ini iklan tersebut 
menampilkan figur foto para tokoh masyarakat atau calon kepala daerah maupun wakilnya, yaitu dengan menampilkan foto diri, lambang partai pengusung, dan kadang disertai slogan dengan berbagai janji-janji. Penampilan iklan inilah yang melatarbelakangi ketertarikan penulis untuk mencermati dan membahasnya dalam tulisan ini. Dalam kasus iklan pilkada ini, penulis tertarik dengan kehadiran fotofoto tokoh yang terpampang pada baliho atau pada media luar ruang yang lain. Berdasarkan tampilnya tokoh tersebut ada yang menarik bila dicermati dari sisi fotografi khususnya dari sisi portraiture photography, baik dilihat dari sisi ide, teknis, maupun estetikanya.

Dalam kajian ini digunakan pendekatan visual methodologies sebagaimana yang dilakukan Gillian Rose (2001), dimana dalam sebuah kajian dengan objek material berupa artefak yang utamanya bisa dilihat, diamati melalui indera penglihatan. Dalam kajian visual terdapat tiga wilayah yaitu dari sisi produksi, karya iklan itu sendiri, dan masyarakat yang mengkonsumsi iklan. Hal ini sebagaimana juga yang terjadi pada kajian iklan pilkada (pemilihan kepala daerah). Adapun wilayah amatan berada di Daerah Istimewa Yogyakarta dan Jawa Tengah. Mengingat Pilkada serentak dilakukan di seluruh wilayah Indonesia dan memiliki aturan yang sama antara wilayah satu dengan yang lainnya, sehingga fenomena yang terjadi secara visual tidak jauh berbeda.

\section{B. Berharap Mendulang Suara Melalui Iklan}

Iklan adalah media komunikasi untuk menyampaikan pesan-pesan dari pihak komunikator (sponsor) kepada komunikan (audience). Secara esensial iklan mempunyai dua peran utama, yaitu sebagai pemberi informasi dan sebagai alat pembentuk pendapat umum (public opinion). Iklan Pilkada tidak jauh fungsinya 
seperti iklan produk komersial yang lain, hanya saja iklan seperti ini dibuat dan dibungkus sedemikian rupa, sehingga akhirnya dapat menciptakan daya tarik yang dapat menggiring audience sesuai yang dikehendaki. Sebagaimana layaknya iklan yang lain, iklan pilkada dalam proses perancangannya diarahkan pada kecenderungan manipulatif. Artinya iklan dikemas dengan berbagai cara menutupi kekurangan dan menonjolkan kelebihan agar audience tertarik. Jadi iklan pilkada tujuannya adalah untuk mengangkat citra tokoh yang ditawarkan sebagai pilihan yang paling tepat. Menurut J. Kristiadi pada Kompas, 25 November 2008 dalam tulisannya menyebutkan bahwa iklan (pariwara politik) terbukti dapat menjadi sarana yang ampuh dalam membentuk dan menggiring persepsi masyarakat. Dalam hal ini iklan pilkada sebagaimana iklan politik dapat mengubah seseorang yang biasa-biasa saja menjadi pemimpin yang kharismatik.

Iklan pilkada bisa dikatakan sebagai sebuah fenomena baru, karena iklan ini belum banyak/ada di zaman Orba. Sebab dimasa Orde Baru kepala daerah pada umumnya ditunjuk dari pimpinan pusat. Namun pada pasca Orde Baru kepala daerah dipilih langsung oleh rakyat, sehingga tokoh-tokoh masyarakat mulai tampil untuk mencalonkan diri apabila terpilih akan menjadi orang terhormat dan sebagai pemimpin di daerahnya. Hampir setiap orang memimpikan dan berlomba untuk mendapatkan kedudukan terhormat. Hal itu adalah sesuatu yang biasa.

Tahun 2015, kembali lagi akan berlangsung pilkada serentak di seluruh wilayah Indonesia yang akan diikuti lebih dari 200 daerah. Berarti ada 200 pasang calon akan berkompetisi untuk menjaring massa agar dapat memenangkan persaingan menjadi kepala daerah dan wakilnya. Calon-calon kepala daerah ini tidak mau kalah dan dapat menemukan pemilihnya dengan berbagai cara yang dilakukan layaknya jualan produk. Ada yang dilakukan dengan cara sowan ke 
orang-orang yang berpengaruh, kunjungan dalam kegiatan keagamaan, membantu aksi sosial yang dilakukan masyarakat, sampai membuat media iklan yang berupa baliho, stiker, poster, dan lain sebagainya. Ditinjau dari dari aturan, menggunakan alat peraga seperti iklan adalah sah, berdasarkan Undang-undang (UU) Nomor 8 Tahun 2015 tentang Pilkada dan Peraturan KPU Nomor 7 Tahun 2015 tentang Kampanye dan alat peraga yang boleh dipasang di tempat-tempat tertentu. Yang dimaksud alat peraga kampanye adalah semua benda atau bentuk lain yang memuat visi, misi, dan program pasangan calon, simbol, atau tanda gambar pasangan calon yang dipasang untuk keperluan kampanye. Selain membolehkan pemasangan alat peraga di tempat umum, peraturan tersebut juga mengatur tentang lokasi-lokasi yang boleh dipasang maupun yang dilarang. Dalam Peraturan KPU tentang Kampanye Calon Gubernur/Bupati/Wali Kota sesuai tahapan pilkada serentak, kampanye calon kepala daerah dilakukan pada 27 Agustus sampai 4 Desember 2015.

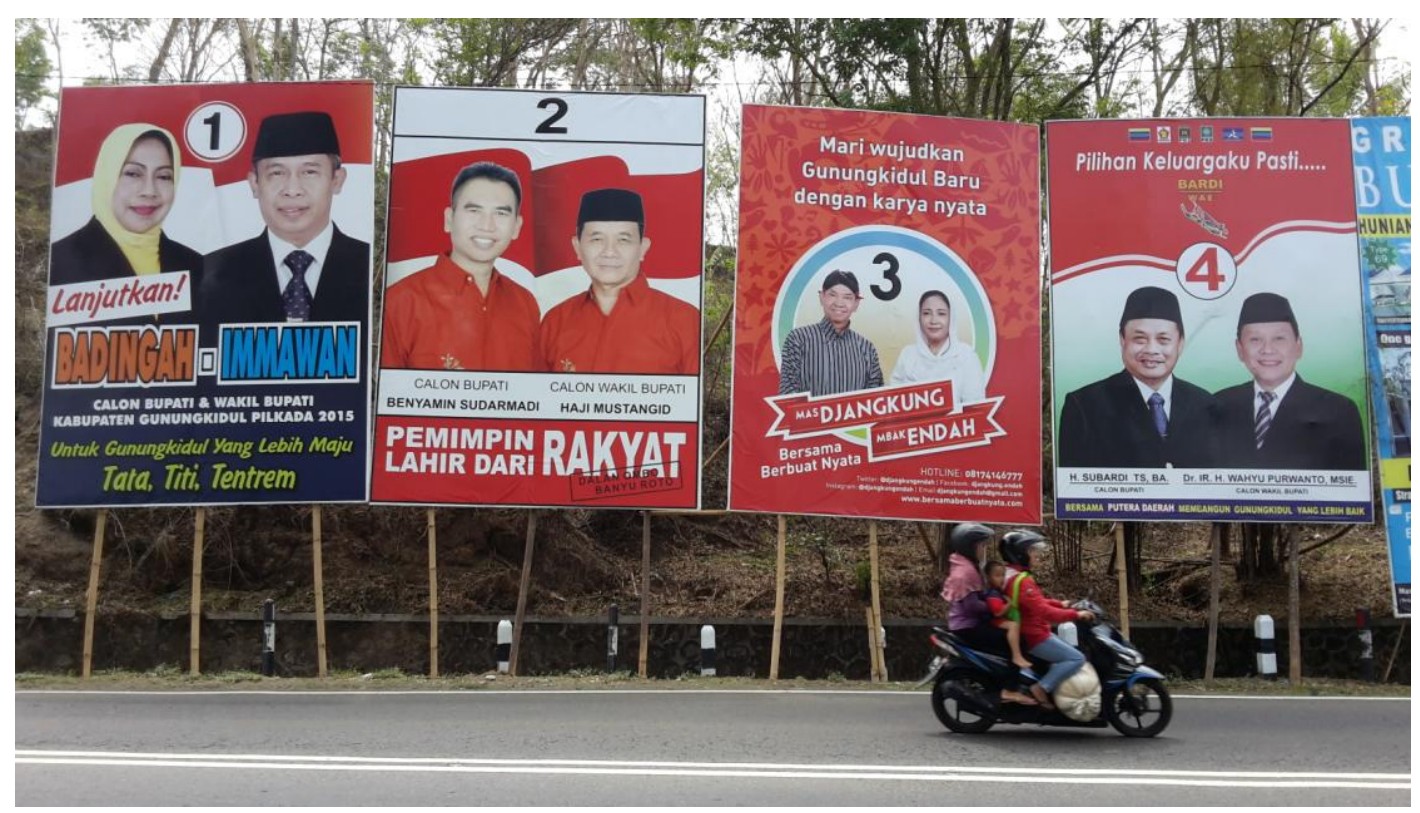

Gambar 1. Agar profil kandidat dikenal masyarakat, maka dibutuhkan media iklan yang berupa baliho. Setiap kali keliling kota dan sepanjang jalan mata dipaksa untuk melihat dan menatap berbagai pesona foto calon kepala daerah yang mengatasnamakan rakyat, pahlawan bagi kemiskinan, bertaqwa, berbudaya, dan janji-janji yang membuai. Tampilan visual foto diri dengan 
berbagai gaya, ekspresi, dan atribut yang digunakan merupakan cara agar calon/kandidat dikenal oleh masyarakat. (Lokasi: Pathuk Gunung Kidul, Yogyakarta)

Untuk memahami modus produksi makna iklan pilkada itu, bisa meminjam konsep dari John Fiske dalam “Television Culture". Produksi makna terjadi melalui tiga (3 tahap) tahap sebagai berikut. Pertama, tahap "Reality". Sebagai iklan pilkada atau partai politik seharusnya memang iklan tersebut tidak datang tiba-tiba dan spontan. Tokoh-tokoh atau figur yang ditampilkan pada media iklan baik yang berupa baliho atau poster di sepanjang jalan diyakini akan memberi pengaruh atau sudah berpengaruh di masyarakat. Secara realita para tokoh ini pada umumnya putra daerah, sehingga sudah ada sebagian masyarakat yang sudah mengenalnya, meskipun dalam lingkup yang belum luas. Maka untuk bisa dikenal secara luas sesuai wilayah yang akan menjadi tanggung jawabnya kelak bila terpilih, mereka berusaha memperkenalkan diri melalui foto diri dengan cara sebaik mungkin.

Kedua, tahap "Representation". Dalam hal ini para tokoh, atau calon yang diusung diharapkan merupakan sosok yang memiliki kelebihan, misalkan sebagai pelopor masyarakat, punya jasa pada rakyat, punya bukti pengabdian yang bisa dibanggakan atau sebagai sosok yang diidolakan di mata rakyat. Selanjutnya adalah tahap ketiga, yaitu tahap ideologi. Ideologi (nilai) dalam iklan politik atau pilkada yang paling banyak disampaikan dan hampir sama adalah setia dengan Pancasila, UUD'45, dan Agamis.

Berkaitan dengan konsep yang dipaparkan di atas, masyarakat bisa menafsirkan secara visual apa yang tampil pada iklan politik atau pilkada yang bertebaran di sepanjang jalan. Iklan lebih merupakan salah satu ciri masyarakat kapitalis dan dampaknya sangat luas. Dalam dunia kapitalis iklan merupakan sesuatu yang tak dapat dihindari karena merupakan kebutuhan, baik dari sisi 
komunikator maupun komunikan. Iklan komersial berfungsi untuk mempertemukan keduanya dalam satu proses pencitraan dan pembentukan nilainilai. Dalam kontek iklan pilkada, di satu pihak iklan bermanfaat untuk memperkuat citra seorang tokoh tertentu, sekaligus juga untuk membentuk image dalam masyarakat tentang person tersebut. Di pihak lain iklan pilkada ini juga bermanfaat untuk komersialisasi tentang konsep (visi dan misi) yang hendak dijual. Semakin tinggi estetika dan citra sesorang tokoh yang ditampilkan, semakin mudah menjualnya. Karakteristik komunikasi melalui media (iklan) adalah bahwa semua informasi yang disampaikan itu dirancang untuk mencapai sebanyak mungkin orang yang menjadi target iklan tersebut (Brunsvick : 2005).

Ciri utama iklan adalah bahwa ia diproduksi atas dasar kepentingan pengirim pesan, bukan atas dasar kepentingaan audiens. Dalam hal iklan pilkada ini, mekanisme perancangan iklan perlu dilatarbelakangi oleh beberapa faktor artistik. Faktor artistik menentukan teknik produksi agar iklan dapat tampil menawan, dalam hal ini tampilan iklan dapat berpotensi memperdaya audiens karena telah didesain sedemikian rupa, yang ditampilkan dalam kemasan yang lebih mempesona.

Nurul Yamin, pada Koran KR 20 Okt 2008, mengatakan bahwa iklan politik yang di dalamnya merupakan iklan pilkada memiliki implikasi antara lain: 1). praktik politik dan praktik bisnis industri menampakkan kepentingan yang sangat erat. 2). fenomena iklan politik menandai pergeseran ke arah industrialisasi dan kapitalisasi politik. 3). Politik telah menjadi komoditi komersial.

Bertolak dari hal-hal yang ditimbulkan iklan pilkada tersebut di atas, bisa dikatakan bahwa iklan pilkada ataupun iklan politik sebenarnya tidak sepenuhnya 
menyuarakan isu-isu yang menjadi kepentingan bersama, melainkan sebatas kepentingan untuk meraih dukungan bagi kekuasaan.

Iklan politik dipandang lebih aman, efektif, dan murah dibanding dengan strategi pengerahan massa. Meskipun demikian iklan dalam pilkada diharapkaan memiliki moral, selain mejaga netralitas, juga mampu menyediakan informasi yang cerdas. Dengan demikian, iklan dalam pilkada tidak sekadar promosi tokoh, melainkan merupakan bagian dari upaya mewujudkan peradaban bangsa.

Oleh karena itu, orisinal atau keaslian desain iklan pilkada perlu diciptakan agar menjadi sebuah karya yang memiliki nilai kebaruan (novelty). Sebuah karya desain yang dikatakan orisinal bisa berupa ide, teknik penyajian, dan nilai pesannya. Namun, yang tidak kalah penting adalah bahwa sebuah karya desain iklan pilkada harus mampu memberikan kontribusi pada kebutuhan publik dan bertujuan untuk memecahkan suatu masalah.

Menurut Robin Landa "The design concept is the creative solution to the design problem. The concept is expressed trough the combination and arrangement of visual and verbal (typographic) material. Succesful concept are innovative and creative, not stereotypical or commonplace." (1981: 49).

Desain yang kreatif adalah desain yang memiliki nilai-nilai yang memberikan solusi dalam mengatasi masalah. Istilah kreativitas sering digunakan untuk menyebut ciptaan baru, yang juga bisa ditinjau dari nilai orisinalitas dan keunikan, artinya di sini juga ada kesegaran ide yang diutamakan, bukan sekadar ulangan atau stereotip. 


\section{Portraiture Photography dan Narsistik}

Kehadiran sosok (foto seseorang) pada iklan pilkada sebenarnya bukan sesuatu yang asing bagi audiens, namun kehadirannya sering luput dari perhatian mata dibanding pada tulisan. Pada saat seseorang mengamati iklan pilkada, hampir dipastikan akan menemukan elemen seperti teks dan gambar (foto wajah seorang tokoh). Keberhasilan suatu iklan jenis display untuk pilkada tersebut tidak bisa dilepaskan dari elemen tersebut.

Dalam iklan pilkada, menampilkan foto seorang calon kepala dan wakil daerah merupakan unsur yang penting dalam mendukung keberhasilan suatu iklan. Selain itu, apabila media iklan yang isinya hanya berupa tulisan tanpa ada elemen lain seperti ilustrasi (gambar) maka akan membosankan bagi yang membacanya. Foto yang ditampilkan dalam iklan pilkada mempunyai tujuan dan harapan agar masyarakat tahu dan mengenal sosok calon pemimpinnya kelak bila terpilih.

Foto yang sering digunakan dalam iklan pilkada ini pada umumnya adalah jenis portrait photography. Portrait photography merupakan jenis fotografi yang merekam gambar dengan objek manusia dengan segala aktivitasnya.. Portrait dapat diartikan foto yang berkaitan dengan orang/manusia sebagai objek utama. Objek utama manusia ini bisa individu/tunggal maupun kelompok atau lebih dari satu orang. Lebih tegasnya foto portrait adalah pengabadian manusia, di mana dalam portrait dibutuhkan pemahaman dan makna, baik itu beauty, mood, maupun happy.

Dalam membuat foto portrait ada beberapa hal yang perlu diperhatikan antara lain sebagai berikut.

1. Pose, antara cara duduk, berdiri, tertawa, dll. Dengan pose yang baik dan tepat akan mampu memberikan jiwa atau karakter pada orang tersebut. 
2. Harmoni, yaitu unsur-unsur yang saling berkaitan dan harus menjadi pertimbangan seperti pakaian, assesori, warna, background, dll.

3. Lighting, perlu memahami kualitas cahaya, arah cahaya, sumber cahaya.

4. Ekspresi, kunci keberhasilan foto portrait adalah apabila kita bisa menangkap ekspresi yang wajar.

Secara umum, pengertian pose dalam potret dapat digiring pada pengalaman citra sebagai bukti eksistensi, bahwa yang dipotret adalah benar adanya, yaitu diri sendiri.

Penampilan iklan pilkada bila tidak diperhitungkan, bahkan jika hanya seadanya, polos, dan tanpa perencanaan yang baik bisa merugikan calon. Foto dalam iklan pilkada dilihat dari fungsinya adalah sebagai ilustrasi dan daya tarik untuk membangun pencitraan diri sekaligus untuk membantu memperjelas isi iklan yaitu menyampaikan pesan visi dan misinya. Menurut Simon Jenning, dalam buku Guide to The New Illutration and Design mengatakan bahwa fungsi ilustrasi adalah sebagai berikut. "Illustration has three main functions these can be loosely described as decorating, informating and comenting." Jadi, foto merupakan salah satu elemen penting yang berfungsi sebagai penghias, artinya sebuah foto memiliki daya tangkap yang efektif dan daya tarik visual yang kuat.

Fotografi menjadi salah satu jenis ilustrasi yang memiliki keunggulan sebagai 'bahasa universal' yang dapat memberikan jalan keluar dari perbedaan bahasa. Seperti dikatakan Lady Elisabet dalam tulisan Soeprapto Soedjono (2006:14), bahwa fotografi merupakan 'medium komunikasi'. Dalam hal ini sebuah karya fotografi dimanfaatkan dalam disain grafis sebagai elemen ilustrasi dalam media cetak seperti iklan cetak karena reliability dalam tampilannya dan dapat meyakinkan konsumen/komunikan. Penampilan ilustrasi dengan fotografi yang 
tampil secara realistik (sesuai produk; sesuai kenyataan) tentu akan lebih meyakinkan dan memiliki nilai persuasif untuk mempengaruhi konsumen. Dengan kata lain karya fotografi lebih komunikatif secara visual.

Fotografi adalah salah satu media yang digunakan untuk menyampaikan gagasan, cerita, peristiwa, berita seperti halnya bahasa. Sehingga foto sangat memungkinkan menjadi alat komunikasi yang komunikatif dan informatif. Sedangkan bila dilihat dalam konteks sebagai bahasa gambar, karya fotografi mampu memberikan pengertiannya sendiri tanpa harus menggunakan kata-kata. David Ogilvy (1983: 76) mengatakan: A picture, they say, can be worth a thousand word. Berdasarkan pendapat di atas dapat disimpulkan bahwa sebuah gambar/foto mampu berbicara, mengungkapkan gagasan, bahkan dapat mewakili ribuan kata.

Sedangkan menurut Earl Theisen : The good photograph shows this feeling, but it must first come to life as a result not only concrete, physical seeing, but also of a sense stimulation that trigers or brings together past experience and new imaginative insight. (1966: 14).

Jadi, mengingat foto merupakan bahasa gambar yang mampu berbicara melampaui ribuan kata, maka foto juga harus mampu menunjukkan dan mempengaruhi suatu perasaan pembaca/penikmatnya. Maka tidaklah salah bila calon kepala daerah cenderung ingin menampilkan foto dirinya (portrait) agar diketahui dan dikenal, dan merasa akrab dengan masyarakat sebagai calon pemilihnya.

Dalam iklan pilkada yang menempatkan alat peraga berupa baliho, spanduk, poster yang sering dijumpai di sepanjang jalan akhir-akhir ini, kebanyakan bernafaskan konsep narsisme. Istilah narsisme berasal dari kata Narcissus, sebuah nama dari seorang pemuda tampan dalam mitos Yunani kuno. Konon suatu hari 
Narcissus menangkap citra wajahnya pada permukaan air yang tenang di hutan, dan sontak ia jatuh cinta pada diri sendiri. Selanjutnya ia putus asa karena tidak mampu memenuhi apa yang sangat diinginkannya; ia bunuh diri dengan sebilah belati. Dari tetesan darahnya yang jatuh di dekat air, tumbuhlah bunga yang sampai sekarang dikenal dengan nama Narcissus.

Menurut Merry Wahyuningsih, narsis atau narsistik dalam istilah ilmiah disebut Narcissistic Personality Disorder (NPD) adalah gangguan psikologis ketika seseorang memiliki rasa percaya diri yang sangat tinggi untuk kepentingan pribadinya dan juga rasa ingin dikagumi (Detik Health : 2011). Narsis atau narsistik merupakan gangguan kepribadian yang menampilkan karakteristik cinta yang berlebihan terhadap diri sendiri. Narsistik ini biasanya ditandai dengan citra diri yang kuat dan superioritas berlebihan. Orang yang narsis ini orang yang suka untuk dikagumi dan mendambakan diri untuk menjadi pusat perhatian meskipun sangat manipulatif. Orang yang bersifat narsis selalu mencari orang-orang yang dapat membantu untuk membuat citra dirinya tinggi. Orang narsis sering melebihlebihkan prestasi dan membual adalah metode yang paling nyaman untuk mendapatkan pengakuan bahwa mereka pantas dan berhak.

Sebagaimana pernyataan tersebut diatas melihat iklan-iklan politik pilkada dengan menampilkan gambar wajah kandidat calon kepala dan wakil daerah dan didukung teks/slogannya bisa disebutkan memiliki kemiripan dengan pengertian narsistik. Sebagai contoh bisa dicermati gambar 2 dan 3, gambar foto wajah kandidat yang digunakan untuk iklan kepala daerah, selain untuk memperkenalkan diri juga sekaligus untuk membangun citra yang mengarah pada konsep narsis. Meskipun mungkin manipulatif mereka ingin dipersepsikan sebagai orang bijak, religius, berakhlak mulia, patriotis, sebagai tokoh yang bisa mengatasi segalanya, 
peduli dengan rakyat, dll. Dalam media iklan pilkada 2015 tersebut baik yang baliho maupun spanduk semua menggunakan atribut yang dipersepsikan masyarakat sebagai orang yang religius, taat beragama, dan berakhlak mulia yang ditandai dengan penggunaan peci bagi yang laki-laki dan berhijab bagi yang perempuan. Selain itu juga diperkuat dengan slogan jujur, ora ngapusi, dekat dengan rakayat, dan mumpuni adalah konsep narsis. Orang narsis sering melebihlebihkan prestasi dan membual adalah metode yang paling nyaman untuk mendapatkan pengakuan bahwa mereka pantas dan berhak. Para kandidat tampil dengan memunculkan ekspresi/mimik wajah yang ramah ditandai dengan senyuman dan kata-kata/janji-janji manis seperti dewa penolong.

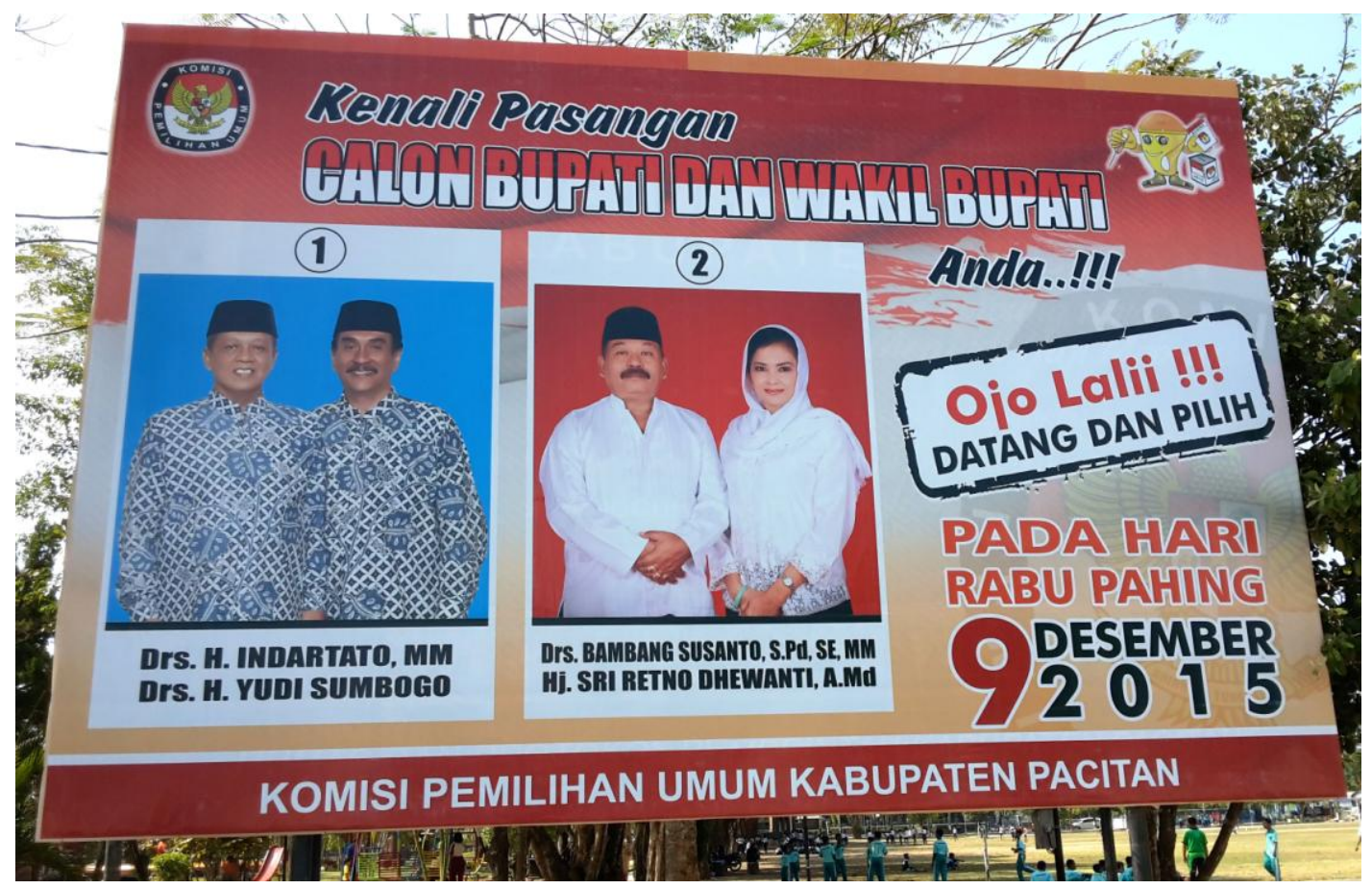




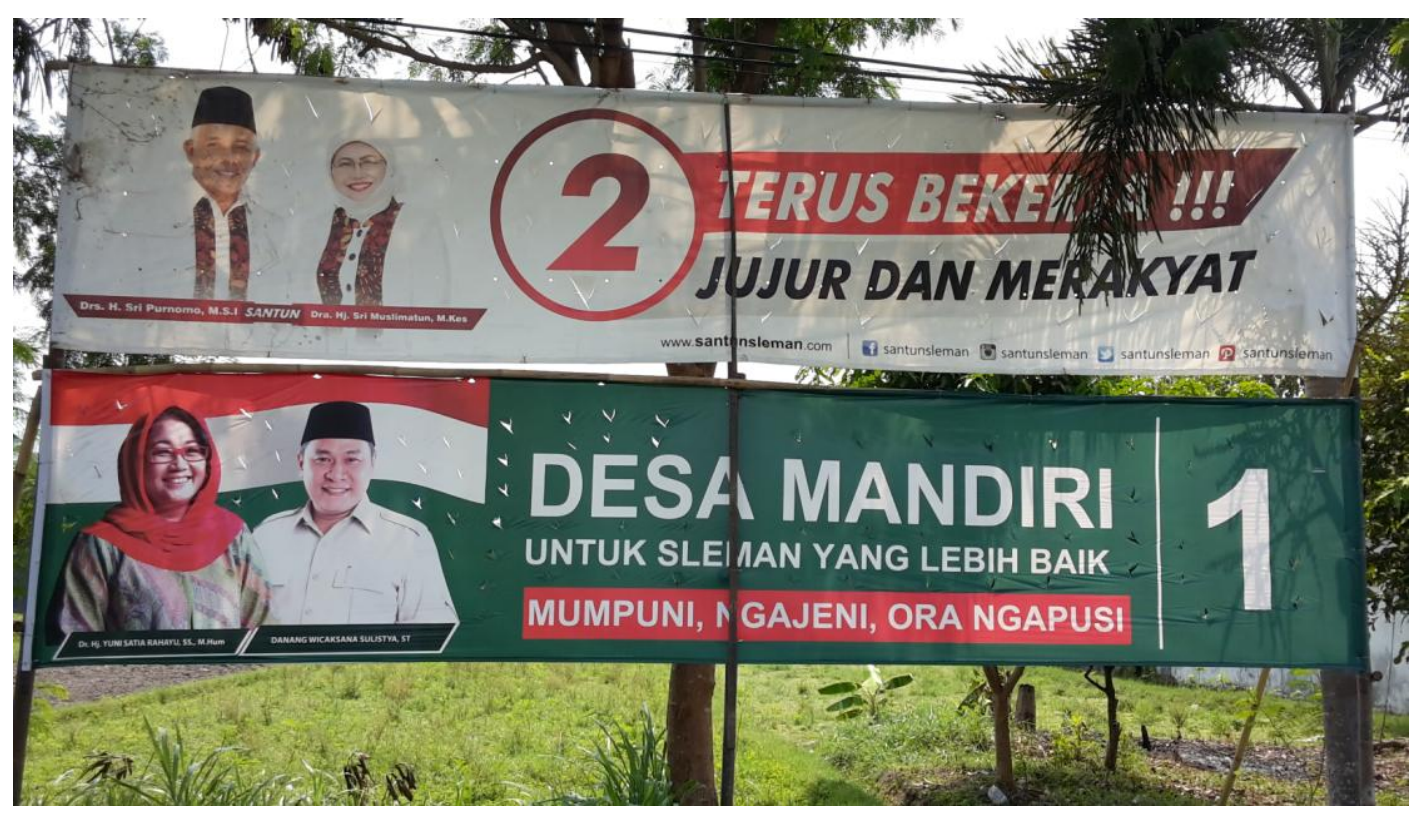

Gambar 2 \& 3: Kandidat kepala dan wakil kepala daerah dari dari kabupaten Pacitan \& Kabupaten Sleman. Narsistik, sifat yang berlebihan terhadap diri sendiri agar mendapatkan pemakluman dengan berbagai gaya dan pesona kepada siapapun yang menatapnya. Gelar akademik dianggap merupakan salah satu daya tarik yang dapat digunakan peserta pilkada untuk menyakinkan pemilih.

Narsisistik adalah kelainan dari seseorang yang cenderung ingin atau minta untuk diperhatikan oleh orang lain. Salah satu penanda narsis dalam pilkada yang lain adalah sederet gelar akademik yang dimiliki dipasang di depan atau belakang nama, ini menjadi aksesoris yang diharapkan dapat mendongkrak daya tarik di hadapan publik. Gelar akademik dianggap merupakan salah satu daya tarik yang dapat digunakan peserta pilkada untuk menyakinkan pemilih. Maka tidak heran, banyak anggota legislatif atau siapapun berusaha untuk bisa mendapatkan gelar akademik dengan berbagai cara, baik yang legal maupun yang tidak legal. Memang setiap bakal calon berhak atas gelar akademik yang dicantumkan sebagai salah satu cara untuk memenangkan pemilu pilkada.

Pemilu, termasuk pemilihan gubernur, bupati, dan wali kota, adalah persaingan antarpeserta pemilu atau antarpasangan calon untuk memperebutkan jabatan yang sama (kepala dan wakil kepala daerah). Karena jumlah jabatan yang diperebutkan sedikit, sementara jumlah yang bersaing ingin mendapatkan jabatan 
itu lebih banyak daripada jumlah jabatan yang diperebutkan dan jabatan itu dipandang amat sangat penting, maka persaingan niscaya akan sangat tajam, bahkan tak jarang menggunakan kekerasan. Para narsistik percaya bahwa dirinya merasa lebih unggul dibanding yang lain.

Maka tidak heran, pesona narsis telah mulai dikobarkan oleh hampir setiap calon yang mengikuti kontestan dalam pemilihan kepala daerah yang akan dilaksanakan secara serentak di seluruh tanah air pada tanggal 9 Desember 2015. Iklan pilkada sebaiknya memang harus berani tampil di luar kelaziman (out of the box), bahkan bisa dikatakan sebagai iklan yang kontemporer. Sebagaimana konsep periklanan modern yang terangkum dalam AIDA (awareness, interest, desire, and action) bahwa iklan harus membangkitkan kesadaran, menarik minat, menumbuhkan keinginan, dan akhirnya bertindak. Untuk itu efek visual sebagaimana gambar foto wajah kandidat sangat penting diperhatikan untuk meningkatkan rangsangan terhadap pesan yang disampaikan. Maka untuk merebut perhatian khalayak terhadap iklan politik dalam pilkada harus berani mencoba sesuatu di luar yang seragam. Sebuah penyajian iklan harus mampu memunculkan skenario dengan daya rangsang sangat tinggi sehingga membuat khalayak berhenti sejenak untuk memperhatikan iklan politik pasangan kandidat.

Kampanye (dalam iklan pilkada), secara substansial dipahami sebagai proses pengenalan diri seorang figur (calon kepala daerah) kepada pemilihnya. Perkenalan diri berisi: siapa dirinya, latar belakang dan prestasi selama ini, pemikiran yang dimiliki, program yang akan dibawa, komitmen, dan strategi untuk memperjuangkan program tersebut. Intinya adalah niat dan kemauan baik yang mendasari perjuangan untuk masa lima tahun ke depan. 


\section{Kesimpulan}

Iklan politik pilkada 2015 pada umumnya banyak didominasi gambar foto wajah kandidat dan tulisan yang berisi slogan janji-janji. Hal ini memperlihatkan bahwa iklan tersebut bernuansa politik narsistik. Iklan seperti ini terkesan ingin memaksakan keinginan atau kehendak agar ingatan masyarakat melekat pada kandidat tertentu. Konsep ini apabila tidak dipahami para kandidat bisa kurang efektif bahkan melahirkan kejenuhan di masyarakat. Terlebih bila gambar/foto kandidat dibuat atau disajikan seperti foto KTP akan melahirkan kesan datar tanpa ekspresi yang menarik serta terkesan pasif. Dalam menyajikan iklan display sebagaimana iklan pilkada, peran gambar/foto adalah sangat menentukan efektif tidaknya sebuah iklan. Untuk itu portraiture photografi perlu mendapatkan perhatian tersendiri.

Pemilihan kepala daerah yang akan dilangsungkan secara serentak pada tanggal 9 Desember 2015, telah menampakkan greget pertempuran antarpara kontestan peserta untuk merebut hati dan simpati rakyat. Salah satunya yang terlihat adalah adanya kompetisi antarpartai politik pengusung dalam memasang atribut, baik dalam bentuk poster, sticker, baliho, ataupun pamflet di pinggirpinggir jalan atau di tempat-tempat strategis seperti area publik. Poster, spanduk, baliho, dan lain sebagainya merupakan salah satu media yang paling banyak diakses oleh masyarakat. Media-media di atas merupakan media konvensional, akan tetapi dalam kenyataannya memiliki kekuatan dan cukup efektif dan lebih murah dibanding iklan televisi dan media cetak massa. Iklan pilkada yang bertebaran di sepanjang jalan tersebut semestinya harus memperhatikan berbagai aspek. Aspek estetika dan etika lingkungan pada setiap penempatannya, aspek bahasa dalam setiap janji yang disodorkan kepada masyarakat. 
Akhirnya penulis berharap agar, iklan-iklan politik yang tampil di tengahtengah publik mempertimbangkan berbagai aspek, antara lain estetika lingkungan di mana media tersebut dipasang, kaidah desain, fotografi, serta etika berpolitik yang mendidik masyarakat.

\section{E. Daftar Pustaka}

Bonnici, Peter, 1998. Designing With Photograpy, Rotovision-Switzerland Batmomolin, Lukas, 2003, Budaya Media Bagaimana Pesona Media Elektronik Memperdaya Anda, penerbit nusa indah, Flores

Budiman, Hikmat, 2002, Lubang Hitam Kebudayaan, Kanisius, Yogyakarta

Barthes, Roland, 1984, Image - Music - Text, Hil and Wang, New York

Brunsvick, Yves, 2005, Lahirnya sebuah Peradaban, Kanisius, Yogyakarta

Geertz, Clifford, 1994, Politik Kebudayaan, Kanisius, Yogyakarta

Jennings, Simon, 1987. The New Guide to Illutration and Design, London: Headline

Klepner, Otto, 1966. Advertising Procedure, New Jersey: Prentice-Hall Inc.

Ogilvy, David, 1973. Ogilvy on Advertising, London: Pan Book Limited

Rose, Gillian (2001), Visual Methodologies, Sage Publications, London.

Soelarko, RM, 1995. Unsur-unsur Utama Fotografi, Semarang: Dahara price

Theisen, Earl, 1966. Photographic Approach To People, New York: Amphoto American Photographic Book Publishing Co. Inc.

Griand, Giwanda (2004), Panduan Praktis Teknik Studio Foto, Puspa Swwara, Jakarta

Soedjono, Soeprapto (2006), Pot-Pourri Fotografi, Penerbit Universitas Trisakti, Jakarta

Kristiadi, J, Kompas, 25 November 2008, Iklan Politik dan Nasib Suatu Bangsa

Yamien, Nurul, Kedaulatan Rakyat, 20 Oktober 2008, Iklan Politik

Ramlan Surbakti, Kompas, Kamis, 18 Juni 2015, Pilkada Serentak Kedodoran

Merry Wahyuningsih, Detik Health, Sabtu, 25 Juni 2011, Narsis Itu Pertanda Diri Mengalami Gangguan Mental 